Discussion Paper No. 13-109

\title{
The Impact of Innovation Off-shoring on Organizational Adaptability
}

Elisabeth Baier, Christian Rammer, and Torben Schubert

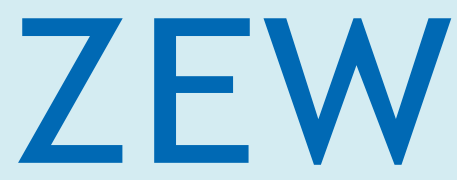

Zentrum für Europäische Wirtschaftsforschung $\mathrm{GmbH}$

Centre for European Economic Research 
Discussion Paper No. 13-109

\title{
The Impact of Innovation Off-shoring on Organizational Adaptability
}

\author{
Elisabeth Baier, Christian Rammer, \\ and Torben Schubert
}

Download this ZEW Discussion Paper from our ftp server:

http://ftp.zew.de/pub/zew-docs/dp/dp13109.pdf

Die Discussion Papers dienen einer möglichst schnellen Verbreitung von neueren Forschungsarbeiten des ZEW. Die Beiträge liegen in alleiniger Verantwortung der Autoren und stellen nicht notwendigerweise die Meinung des ZEW dar.

Discussion Papers are intended to make results of ZEW research promptly available to other economists in order to encourage discussion and suggestions for revisions. The authors are solely responsible for the contents which do not necessarily represent the opinion of the ZEW. 


\title{
The Impact of Innovation Off-shoring on Organizational Adaptability
}

\author{
Elisabeth Baier ${ }^{\mathrm{a}}$, Christian Rammer ${ }^{\mathrm{b}}$, Torben Schubert ${ }^{\mathrm{c}^{*}}$ \\ ${ }^{a}$ PTV Group AG, Haid-und-Neu-Straße 15, 76131 Karlsruhe, Germany \\ b ZEW, L 7, 1, 68161 Mannheim, Germany \\ c CIRCLE, Lund University, Sölvegatan 16, 22100 Lund, Sweden, and \\ Fraunhofer ISI, Breslauer Straße 48, 76135 Karlsruhe, Germany
}

December 2013

\begin{abstract}
We analyze the effects of captive off-shoring of innovation activities on the firms' ability to adapt their organizational processes and structures. Starting from complexity theory, we use three consecutive waves of the German part of the Community Innovation Survey to test our hypotheses. We find an inverted u-shape of innovation off-shoring on the effectiveness of organizational adaptability, implying an optimal threshold value of innovation off-shoring. This value is $11 \%$ for share of off-shored R\&D, $15 \%$ for downstream innovation activities such as local market adaptation, and 34\% for design activities. We also analyze several contingency variables. In particular we show that the costs of innovation off-shoring in terms of reduced organizational adaptability are exacerbated by a strong focus on $\mathrm{R} \& \mathrm{D}$ and a strong embeddedness in on-shore networks. Smaller firms find it easier to deal with the management complexity induced by geographical dispersion of innovation activities because of their greater flexibility.
\end{abstract}

Keywords: Internationalization, Off-Shoring, Innovation, R\&D, Organizational Adaptation, Organizational Adaptability

JEL-Classification: O32, M16, L23, L25

* Corresponding Author: phone: +49 7216809 357, e-mail: torben.schubert@circle.lu.se 


\section{Introduction}

Internationalization of firm operations has become an increasingly important topic in management practice and has evolved from an exotic niche strategy to a standard management decision (Rilla and Squicciarini, 2011; Hätönen and Erikson, 2009). Beyond the scope of simple manufacturing processes, increased internationalization can now also be observed in highly knowledge-intensive processes, such as innovation (Henley, 2006; Levy, 2005; Bardhan and Jaffe, 2005; Lewin et al., 2009).

Reflecting this increasing importance there is a growing literature on the topic of innovation off-shoring1 including studies on motives and choice of location (Ambos and Ambos, 2011; Jensen and Pedersen, 2011) as well as the impacts on firm performance (cf. Fifarek et al., 2008; Nieto and Rodriguez, 2011; Kotabe et al., 2007 for the impacts innovation capabilities; cf. Nieto and Rodriguez, 2013; Tang and Livramento, 2010 for impacts on productivity).

While it is commonly held that off-shoring requires also organizational restructuring, these aspects were not at the center of interest (cf. the literature review in Schmeisser, 2013). Only recently a literature has emerged that relates off-shoring to arguments about organizational complexity and modularity. On the one hand it is argued that off-shoring increases organizational complexity and hence reduces the organizational ability to adapt to changing environments (Bals et al., 2013; Larsen et al., 2013). On the other hand, Kedia and Mukhherjee (2009) and Nieto and Rodriguez (2013) claim the existence of disintegration advantages associated with off-shoring facilitating adaptation.

Understanding about how these seemingly contradictory arguments interact is not only important for questions of how optimal organizational structures in offshoring companies look like. By shedding lights on both organizational costs and benefits it can also provide potentially valuable insights into why companies offshore and, in some case, why they fail and backshore (Kinkel and Maloca, 2009; Kinkel, 2012).

We attempt to contribute to the literature both in a theoretical and an empirical respect. First, we seek to reconcile the contradictory arguments on organizational consequences of innovation off-shoring within the framework of complexity theory. We will argue for an inverted u-shape relationship between innovation off-shoring and organizational

1 In defining innovation in relation to R\&D we follow the definitions OECD manual (OECD and EUROSTAT, 2005). R\&D is a subset of all innovation activities in two respects. First, innovation includes activities such as organizational and marketing innovation that are not part of R\&D. Second, a defining characteristic of R\&D is that it needs to be systemic and to some degree planned. Innovation activities need not fulfill this requirement. 
adaptability implying an optimal threshold of innovation off-shoring. Below this threshold, innovation off-shoring facilitates organizational adaptability through disintegration advantages as hypothesized by Kedia and Mukhherjee (2009). Beyond that threshold, off-shoring becomes detrimental reflecting the increasing costs of organizational complexity. Second, we test our theoretical framework using data from three waves of the German Innovation Survey, including a survey wave that collected detailed information on off-shoring activities related to innovation for a large, representative sample of firms. This unique data allows contributing quantitative analyses to a strand of literature that so far has remained largely theoretical or based on case studies.

We also investigate several moderating factors of the effect of off-shoring on organizational complexity. We show that innovation off-shoring decreases the effectiveness of organizational innovation more strongly when firm's strategic focus on $R \& D$ is large and domestic R\&D collaborations play an important role. In addition, the geographical dispersion of off-shoring activities and associated institutional complexity can be handled more efficiently by small rather than large firms.

\section{Theory}

Current theorizing about the benefits and costs of innovation off-shoring and outsourcing has frequently adopted the perspective of the resource based or capabilities view, often in combination with arguments from transaction cost theory. Within this theoretical framework, off-shoring impacts are analyzed in terms of changes of internal capabilities. One strand of literature emphasized the importance of tapping into new knowledge sources (Maskell et al., 2007; Bardhan and Jaffe, 2005; Barthélemy and Quélin, 2006; DeSarbo et al., 2005), leading to the generation of gains from resource complementarity with existing internal knowledge sources (Cassiman and Veugelers, 2006). On the cost side, it has been argued that internal resources may be weakened by excessive use of external knowledge (Grimpe and Kaiser, 2010), that a firm's integrative capabilities may be hampered (Helfat and Raubitschek, 2000; Grimpe and Kaiser, 2010), and that a strong focus on external knowledge sourcing in innovation processes in order to substitute own $\mathrm{R} \& \mathrm{D}$ efforts could reduce the absorptive capacities of the organization (see Cohen and Levinthal, 1990).

The resource based perspective has proven useful for the analysis of the impacts of offshoring on the firms' capabilities. For example Kotabe et al. (2007), Nieto and Rodriguez (2011) and Grimpe and Kaiser (2010) use this perspective to analyze the impact of innovation off-shoring and outsourcing on a firm's overall innovation capabilities.

Moving beyond the view that costs or benefits of off-shoring primarily emerge through impacts on internal capabilities, some recent contributions have identified the implied 
changes in managerial complexity as one of the most important challenges of offshoring (Bals et al., 2013; Jensen et al., 2013). We will follow this line of research and by linking innovation off-shoring to complexity theory (Simon, 1962, 1996, 2002). Complexity theory offers a framework to analyze the consequences of firm decisions on organizational adaptability and organizational innovation.

We continue by presenting some basic ideas of complexity theory in the next section and combine them with insights from existing literature on innovation off-shoring to derive our research hypotheses in Section 2.2.

\subsection{Elements of Complexity Theory}

Complexity theory (Simon, 1996, 2002; see also Simon, 1962) investigates design principles of complex systems. Its key concept is the nearly decomposable system (NDsystem). ND-systems are often visualized with reference to task matrices. Supposing there are $\mathrm{N}$ tasks of which $\mathrm{j}$ and $\mathrm{i}$ denote two particular ones, then a task matrix is a matrix of dimension $\mathrm{N}^{*} \mathrm{~N}$, where cell $(\mathrm{j}, \mathrm{i})$ describes the dependence structure between task $\mathrm{j}$ and $\mathrm{i}$. If there exists a way of assigning tasks to a fixed number $\mathrm{K}$ of groups such that the dependence exists only within but not between groups, then a system is said to be decomposable with respect to these K groups (cf. Zhou, 2013). The main postulation of complexity theory is that decomposable and appropriately decomposed systems are able to adapt to environmental turbulence fast (Simon, 2002; for simulation results see for example Frenken et al., 1999; Rivkin and Siggelkow, 2007; Ethiraj and Levinthal, 2004; Yayavaram and Ahuja, 2008).2

While decomposability is a theoretical attribute of a given system, much of the management research has focused on disintegration as comprising all actual processes that split integrated system into separated subsystems. We follow Bals et al. (2013) and Nieto and Rodriguez (2013) who note that from an organizational perspective offshoring is a process of decomposing organizational processes, production activities and value chains.

Most authors tend to see both benefits and costs of decomposing firm activities, implying a trade-off between decomposition and performance. Concerning benefits, Kedia and Mukherjee (2009) argue for advantages of organizational decomposability. Decomposition can reduce complexity because it allows managers to focus on more narrowly defined problems (Zhou, 2013). On the cost side, decomposition increases the need for coordination between subunits because tasks are rarely fully independent of

2 As Simon (2002) points out, if subsystems are linked by some sort of interdependence, the optimum state of the entire system can only be found when all subsystems are jointly optimized. If subsystems are independent the global optimum of the entire system can be found by optimizing each subsystem individually. 
each other, implying almost always a need for interfaces between tasks that have been decomposed. The more complex these interfaces become the less effective organizational changes will be because complexity makes it difficult for managers to predict organizational impacts of certain changes correctly (Ethiraj and Levinthal, 2004) and thus undermines the ability to respond to environmental change (Robson et al., 2008). This implies both adaptability increasing and decreasing effects and suggests a trade-off that must be balanced at an optimal level of decomposition.

Because we understand off-shoring as an instance of a process of decomposition, the degree of off-shoring governs this trade-off.

\section{$2.2 \quad$ Derivation of Hypotheses}

\subsubsection{The General Relationship}

Both the existence of costs and benefits of off-shoring and outsourcing in general have been frequently discussed. Concerning benefits, Hedlund (1999) stresses the role of knowledge recombination and states that the opportunity created by organizational turbulence "will mostly not be fruitfully addressed by further decompositio". This is closely related to the arguments of Kedia and Mukhherjee (2009) on the existence of disintegration advantages leading to organizational modularity (cf. also Schmeisser, 2013). On the cost side, Medcof (2001) argues that off-shoring causes major disruptions in the organization of the value chain and, to the degree that these costs are not addressed, they may exceed the benefits. Lampell and Balla (2011) argue that offshoring of high-value strategies is very difficult because these activities are tightly coupled to other functions in the firm inflating costs of interface creation.

The existence of a trade-off between costs and benefits of off-shoring makes a strong point for an inverted u-shape-relationship between off-shoring and organizational innovation. Indeed for related research questions such a relationship has been found. Focusing on overall firm performance and the degree of internalization of firm activities an inverted u-shape has been hypothesized already by Hitt et al. (1994) and Sullivan (1994). Empirical evidence was found by Geringer et al. (1989), Gomes and Ramaswamy (1999) and Hitt et al. (1997). Other studies arguing for inverted u-shapes moved beyond general measures of firm performance and analyzed the relationship between outsourcing and innovation (Grimpe and Kaiser, 2010) and off-shoring and innovation (Kotabe et al., 2008).

Both on the basis of the theoretical arguments stemming from complexity theory in the preceding section and based on prior results in the related literature we therefore hypothesize that a u-shape also extends to the relationship between innovation offshoring and organizational adaptability. Organizational adaptability is used here to denote the effectiveness of organizational changes with respect to performance. 
H1a: The degree of innovation off-shoring has an effect on the effectiveness of organizational innovation that follows an inverted u-shape.

Beyond the general relationship, it has been held that also the task characteristics (in terms of their routine, complexity, interconnection) may be very important, implying that a simple differentiation between e.g. innovation versus manufacturing might be inappropriate (Ørberg Jensen and Pedersen, 2011; Liu et al., 2011). In the context of this paper that means that the general relationship between innovation and the success of organizational adaptations will also depend on the exact type of innovation activity that is off-shored. It is common to distinguish between R\&D (i.e. activities devoted to develop new technology), design (transferring new technology into marketable products and routine processes), and downstream activities (implementing innovations in production, marketing of innovations). The general expectation is that more complex and more interconnected activities are likely to stay at the headquarters (Mudambi, 2008). Accordingly, D’Agostino et al. (2011) suggests that firms focus on off-shoring standardized innovation activities such as design, while they retain core R\&D activities as well as marketing-related innovation activities at home since these are more closely interconnected with other functional departments.

H1b: The optimal threshold is lower for core $R \& D$ and marketing-related innovation than for design.

\subsubsection{Moderating Factors}

The general relationship is likely will be contingent on moderating factors. We will turn to these now.

\section{Geographical Dispersion and Firm Size}

Contractor et al. (2010) argue that there is a subtle difference between internationalization of innovation in general and the degree of geographical dispersion. The general expectation is that geographical dispersion increases organizational complexity and thereby amplifies the costs of off-shoring. Greater geographical dispersion does not only increase physical transaction costs, it also increases cultural and or institutional proximity. Thereby it amplifies social communication costs, risks of culturally determined misunderstanding and institutionally determined transaction costs. We thus expect:

H2a: The optimal threshold for off-shoring innovation is lower when geographical dispersion is high.

The ability to deal with additional complexity also depends on the degree of initial complexity, which can be proxied by size of the firm. In this context, Larsen et al. (2013) proposed the concept of combinatorial complexity, which refers to the fact that 
in a system of $n$ subsystems the number of possible linkages is equal to $n *(n-1)$. Taking this number as a proxy for complexity, we see that it is quadratic in the number of subsystems, implying that complexity rises more than proportionately with size. In a similar vein, Roza et al. (2011) argue that smaller firms possess important virtues such as organizational flexibility and entrepreneurial dynamism. The underlying argument is that smaller firms are generally less complex and find it easier to manage globalized value-chain activities. These arguments are empirically backed by the existence of "born-globals" (e.g. Knight and Cavusgil, 1996) and the increasing importance of offshoring in SMEs (Di Gregorio et al., 2009). In line with the argument of lower combinatorial complexity in smaller firms we derive the following hypothesis:

H2b: Small companies find it easier to deal with geographical dispersion of their innovation processes.

\section{The Role of On-shore Innovation Networks}

Besides firms' organizational management capabilities, local links in domestic networks play a decisive role in innovation processes (Boehe, 2007). Off-shoring can have significant impacts on these networks and on local embeddedness of firms. For example in the case of outsourcing, it has been shown that local embeddedness in networks reduces the potential for successful outsourcing (Grote and Täube, 2007). Though offshoring may increase a firm's external links, it can also weaken a firm's network because established links may be dissolved when approaching new suppliers or customers abroad. At the same time, it is not easy to establish the same links abroad because organizational routines tailored to this task are usually too specific to transfer (Ebersberger and Herstad, 2011; Schmidt, 2010), as such routines build on social capital and trust among partners (Laursen et al., 2012). There is both a geographical and a temporal dimension to this argument. First, trust and social capital accumulate over time, implying that recent off-shorers might have to deal with low levels of trust and social capital initially. Second, traditional substitute mechanisms, such as monitoring, are less effective (Ceci and Prencipe, 2013), when distance is increases making network coordination more difficult. Thus, effect of off-shoring on network embeddedness will tend to be negative. Because of the critical importance of R\&D collaboration for the ability to innovate successfully (Aschhoff and Schmidt, 2008), and the positive complementarity between technological innovation and organizational change (Schmidt and Rammer, 2007), weakened onsite innovation networks should also imply a lower ability for effective organizational adaptations.

H3: The effect of innovation off-shoring on organizational adaptability is negative for firms that are more strongly involved in domestic $R \& D$ collaborations. 


\section{Strategic Focus on R\&D}

The impacts of off-shoring will also depend on the role that innovation plays for the firm and thus on the strategic focus. In the context of outsourcing it is often seen as detrimental when the outsourced activities refer to core competences (Contractor et al. 2010) because of the increased danger of knowledge leakage and moral hazard (Sampat 2004). These opportunism-related issues are sometimes argued not to apply to captive off-shoring because conflicts of interest are assumed to be low within the organizational boundaries of the firm. Yet, on the other hand misalignment of interests also exists within firms, for example for managers at different levels. Fama (1980) makes this quite explicit when he conceptualizes the firm as a nexus of contracts. Furthermore, geographical distance makes several mechanisms mitigating such misalignments, in particular trust and monitoring, much less effective (Ceci and Prencipe, 2013). Therefore opportunism is likely to be an issue also in captive off-shoring settings. A general recommendation has therefore been that firms should keep tight control of their core activities, also in a geographical dimension, because the risks can be substantial (Maskell et al., 2007). This argument is compatible with complexity theory. If interfaces need to be created between disintegrated value chain activities, such interfaces become more complex to implement when conflicts of interest and opportunism are substantial.

Many authors have treated innovation activities generally as core activities, which would imply that R\&D should not be off-shored. Despite that, Contractor et al. (2010) highlight that the constructs core/non-core are determined on a grey-scale. Therefore, we argue that the costs of off-shoring $R \& D$ are higher when the strategic focus on $R \& D$ is stronger, which we measure by the $R \& D$ intensity.

H4: The effect costs of off-shoring internal $R \& D$ on organizational adaptability is the more negative the higher the $R \& D$-intensity is.

\section{$3 \quad$ Data and Empirical Identification Strategy}

\subsection{Data}

The data used to test the hypotheses is taken from the Mannheim Innovation Panel (MIP). The MIP is an annual survey of innovation activities of German enterprises. The MIP is the German contribution to the Community Innovation Surveys (CIS) of the European Commission and fully complies with the methodological standards laid down for the CIS. In contrast to the bi-annual CIS, the MIP survey is conducted annually, providing more opportunity for panel analysis. The MIP is based on a stratified random sample of enterprises located in Germany with 5 or more employees that have their main economic activity in mining, manufacturing, energy and water supply, sewerage and remediation, wholesale trade, transportation and storage, information and 
communication services, financial and insurance activities, and other business-oriented services. More details on the MIP can be found in Peters and Rammer (2013).

For this paper we use information from three survey waves, 2006, 2007 and 2009. The 2006 wave collected detailed information on firms' innovation off-shoring activities. Each firm reported the type and extent of off-shored innovation activity with respect to product and process innovations, distinguishing five types: R\&D, design, production of new products/services, introduction of new process technology, marketing of new products/services. For each type, the share of off-shored activities in the firm's total innovation activities was obtained, using three categories: 1 to $10 \%, 11$ to $50 \%,>50 \%$ of a firm's total innovation activities of the respective type. In addition, each firm with off-shored innovation activities was asked to name the countries where these activities took place for each of the five types of activities. The information on innovation offshoring refers to activities in the year 2005.

The 2009 wave contains information on organizational changes and their impact on firm performance which is used to construct a measure of organizational adaptability. In line with the recommendations of the Oslo Manual (OECD and Eurostat, 2005), three types of organizational changes are distinguished: new business practices for organizing procedures, new methods of organizing work responsibilities and decision making, and new methods of organizing external relations with other firms or public institutions. Five types of performance impacts of organizational changes are covered: reducing time to respond to customer or supplier needs, improving ability to develop new products or processes, improving quality of goods or services, reducing costs per unit output, and improving communication or information sharing within the firm or with other enterprises or institutions. Data on organizational changes and their impacts refer to 2006-2008, i.e. the three years following the period for which off-shoring activities were reported. The 2007 wave is used to construct various control variables for a firm's propensity to introduce organizational changes and its ability to yield certain performance effects from these changes.

Note that in what follows we restrict our sample to firms with headquarters in Germany for all three years. That means that we exclude firms which are subsidiaries of multinational companies with headquarters outside Germany. These firms represent 6 percent of the sample. The approach guarantees a clear meaning of the terms 'on-shore' and 'off-shore'. Additionally, we exclude all firms with no innovation expenditures in 2005 because the question of off-shoring innovation is meaningless for them.

We end up with a sample of 447 innovation-active firms that responded in all three MIP waves and had their headquarters in Germany. Due to the item non-response, the net sample of firms used for model estimations is between 258 and 271. 


\subsection{Core Variables}

Our dependent variable is organizational adaptability (OA), i.e. the ability of a firm to change organizational routines and processes in a way to improve the firm's performance. We measure organizational adaptability by the extent to which organizational changes introduced in the field of business practices, work organization and external relations during a three-year period yield to significant positive changes in firm performance, distinguishing five performance dimensions: reaction times, development capabilities, product/service quality, production costs, and communication flows. For each dimension, firms provided an assessment of the impacts of organizational changes on these five performance dimensions using a 4-point Likert scale which takes the values none, minor, medium, and large. We build six alternative dependent variables: one for each performance dimension plus an aggregated index that sums up the five individual dimensions by assigning values of 0 to 3 to the four point Likert scale. The aggregated OA index can range from 0 to 15 . Note that firms that did not introduce any organizational change during a three year period receive a value of zero for all OA variables. Since OA is an ordered discrete response variable, we use ordered probit regression.

The key variable to explain organizational adaptability is the share of off-shored innovation activities. While off-shoring of innovation almost certainly requires some organizational changes in order to accommodate the changes in the innovation process, the decisive factor is whether off-shoring affects the future success of organizational changes in the firm. We distinguish three types of off-shored innovation activities: R\&D, design, and downstream activities (where the latter comprises the implementation of new production technologies, the production of new products/services, and marketing of new products/services at off-shore locations). For each type we determine the share of off-shored activities by assigning the mean value of each category (i.e. 0.055 for 1 to $10 \%, 0.305$ for 11 to $50 \%$, and 0.75 for $>50 \%$ ).

Distinguishing these three types is important to test our hypotheses. H1a basically makes a postulation about the general effect of innovation off-shoring on organizational adaptability, assuming an inverted u-shape while H1b postulates differences by type of innovation activity. In order to test this hypothesis, we analyze the effect of the share of off-shored innovation activities and its squared term on OA for each type of innovation activity separately. From the regression results we calculate the thresholds and compare them across type of innovation activity.

H2a investigates whether geographical dispersion amplifies costs associated with complexity. We measure relative geographical dispersion by the share of off-shore locations at which not all three types of innovation activities (R\&D, design, downstream activities) were simultaneously performed. We include this variable as moderator for the share of off-shoring by type of innovation activity. 
H2b states that smaller firms are better able to deal with geographical dispersion. We therefore analyze whether the geographical dispersion variable is moderated by firm size, separating between small to medium-sized ( $<500$ employees) and large firms ( $>=500$ employees). The reason for not using a continuous size measure such as the number of employees is because we think that the argument made is more of a categorical type, because large companies at a certain level of size radically change their organizational structures rather than evolving on grey-scales. Therefore, we think a dichotomous indicator captures better what we would like to measure. Note that when using a continuous measure, results do not change fundamentally.

H3 postulates that stronger involvement in on-shore innovation collaborations tends to produce less favorable outcomes when innovation activities are off-shored. We measure the strength of this involvement by the extent of innovation networks. As a proxy for network extent, we take the number of different types of partners a firm collaborates with. Seven types of partners are distinguished: companies within the same enterprise group, customers, suppliers, competitors, consultants, universities, and public research institutions. The variable ranges from zero (when the firm had no onsite innovation collaborations) to seven (when it had collaborations with all types of partners).

In $\mathrm{H} 4$ the moderating variable is R\&D-intensity. We include an interaction variable of off-shored R\&D and a firm's R\&D-intensity (as measured by R\&D expenditures over sales) to test this hypothesis.

For H1-H3 we report results for the OA index only since the results for each of the five performance dimensions of OA are very similar to those for the OA index. For H4, however, there is a marked difference by performance dimension. That is why we report the results for each performance dimension separately.

\subsection{Confounding Factors}

For more than 15 years researchers have been investigating empirically the drivers behind the internationalization of $R \& D$ and innovation, which serve as basis for the identification of major confounding factors in the following empirical investigation (cf. Bartlett and Ghoshal, 1998; Gassmann and von Zedtzwitz, 1999). In order to accurately identify the effect of innovation off-shoring on organizational adaptability, a number of confounding factors that are correlated both with the off-shoring decision as well as with organizational adaptability will be included in the regression models. Based on earlier findings, four groups of confounding factors are regarded as particularly relevant: size, group structure, export activities, and past experience with off-shoring activities. Besides these four main groups, further factors appear frequently in related discussions, including market structure and the competitive environment, knowledge and capital intensity of the production process, R\&D expenditures, location of headquarters as well as industry affiliation. 
Size: Size is an important confounding factor with respect to off-shoring activities. While earlier studies found that primarily large firms tend to off-shore (Bardhan and Jaffe, 2005), more recent literature contributions were able to show that also small and medium-sized firms undertake off-shoring activities, though off-shoring by SMEs is often driven by different factors (Roza et al., 2011). On the basis of these partly contradicting results, we have no a-priory expectation on the impact of size (measured by the number of employees) on organizational adaptability.

Group structure: The argument about size is closely related to the prevalent group structure. It is already known for several decades that different organizational structures support or hamper organizational adaptability (Chandler, 1977; Miles et al., 1978). As regards geographical dispersion of enterprise activities, subsidiary management is likewise an important influencing factor, in particular with respect to the degree of independence as well as flows of capital, knowledge and products between the parent and the subsidiary (Bartlett and Ghoshal, 1998; Birkinshaw and Hood, 1998). In particular, group structure may influence inbound off-shoring activities of enterprises. Based on complexity theory we believe that firms that belong to a group are much more accustomed to management of multi-site processes and therefore may find it c.p. easier to introduce organizational innovations. Note that this argument is different from the size argument because it makes a statement about organizational structure and not size. We deem the dummy equaling unity if the company belongs to a group to be positive.

Export activities and past experience with off-shoring: Export activities increase the likelihood of off-shoring activities because of the increasing need to adapt products to local markets and to interact closely with the customers (Kuemmerle, 1999; Gassmann and von Zedtwitz, 1999). Past experience in off-shoring will also lead to higher offshoring activities in the present, not only because of sunk costs and path dependence but also because of management learning (Ørberg Jensen, 2009). At the same time export activities and past off-shoring might also impact on organizational learning (Gassmann and von Zedtwitz, 1999; Macharzina et al., 2001) and thus stimulate organizational adaptability. This is because export activities are rarely organized as completely remote selling activities abroad but need interactions with foreign customers. Therefore, export activities often imply an increased geographical dispersion of the value chain that may raise the need for organizational adaptations. Management learning is likely to improve handling of geographical dispersion of firm activities. Prior off-shoring experience and related capabilities to manage multi-site value chains should positively affect organizational adaptability. We measure off-shoring experience by a dummy that takes the value one if a firm had firm activities other than innovation at locations abroad in 2005. On the other hand, stronger internationalization implies higher complexity. The direct impact of exports remains therefore theoretically unclear.

Market share of the firm: The market share of the firm might impact off-shoring decisions, as being closely related to competitive structures on the domestic and foreign 
markets. On the one hand competition may increase the profit from innovating; on the other hand, competition may reduce innovation incentives for laggards (Aghion et al., 2005). The market share of the firm reflects the market power and determines the overall enterprise strategy and its innovation strategy.

$R \& D$ intensity and sector dummies: $\mathrm{R} \& \mathrm{D}$ is one of the main drivers of innovation at the firm level, and each firm faces the choice between not-investing in $R \& D$ and investing in $R \& D$ activities. Since R\&D intensity varies according to sector affiliation, but also from firm to firm both aspects are to a certain degree interrelated. These considerations have led to the conclusion to include sector dummies according to the OECD classification of technology levels (OECD, 2007) and R\&D intensity as control variables.

The share of material costs in total costs: This variable is included as a measure of capital intensity. Literature findings are not very clear about the effects of capital intensity on innovation. On the one hand capital intensity is positively related to the number of patents, but negatively related to innovation (Acs and Audretsch, 1989). The direct effects of this variable remain unclear.

A dummy for a location in eastern Germany: The rationale for the inclusion of this rather unusual control variable stems from the origin of the data used for testing the hypotheses. The data is derived from the Mannheim Innovation Panel (MIP), an annual survey of innovation activities of German enterprises. Since industrial structures and management practices are still quite different in the eastern and western part of Germany to control for the location seemed natural.

\section{$4 \quad$ Results}

\subsection{Descriptive Results}

Table 1 presents summary statistics for the main variables used in this paper. We provide this table as a reference for the reader. Yet, the analysis of the sample with respect to off-shoring activities is more interesting (see Table 2 and 3).

We computed a general measure of innovation off-shoring by taking the mean value of the share of three types of off-shored innovation activities: R\&D, design, and downstream activities. We analyze this variable with respect to internal R\&D activities and size (Table 2) and with respect to sector (Table 3) using OECD’s technology-level classification (OECD; 2007). 
Table 1: Descriptive Statistics

\begin{tabular}{|c|c|c|c|c|}
\hline Variable & Mean & Std. Dev. & Min & Max \\
\hline OA: General & 5.18 & 5.10 & 0 & 15 \\
\hline OA: Reaction time & 1.14 & 1.21 & 0 & 3 \\
\hline OA: Development capability & 0.95 & 1.11 & 0 & 3 \\
\hline OA: Quality & 1.14 & 1.22 & 0 & 3 \\
\hline OA: Production costs & 0.84 & 1.03 & 0 & 3 \\
\hline OA: Communication & 1.12 & 1.17 & 0 & 3 \\
\hline Market share (\%) & 22.29 & 26.40 & 0.00 & 100 \\
\hline Share material costs (\%) & 53.93 & 23.41 & 0.09 & 100 \\
\hline Employees & 2260.88 & 22164 & 0 & 475000 \\
\hline Export intensity & 0.20 & 0.26 & 0.00 & 1.00 \\
\hline $\mathrm{R} \& \mathrm{D}$ intensity & 0.04 & 0.14 & 0.00 & 2.08 \\
\hline Eastern Germany (d) & 0.37 & 0.48 & 0 & 1 \\
\hline Group member (d) & 0.44 & 0.50 & 0 & 1 \\
\hline Share off-shored R\&D (\%) & 2.07 & 8.77 & 0.00 & 75 \\
\hline Share off-shored design (\%) & 2.04 & 8.15 & 0.00 & 75 \\
\hline Share off-shored downstream activities (\%) & 4.04 & 8.84 & 0.00 & 75 \\
\hline \# types domestic R\&D partners & 0.98 & 1.51 & 0 & 7 \\
\hline Relative geographical dispersion (\%) & 95.93 & 19.77 & 0.00 & 100 \\
\hline Off-shoring in 2005 (d) & 0.25 & 0.43 & 0 & 1 \\
\hline Off-shoring proximity & -0.01 & 0.36 & -3 & 1 \\
\hline Medium-high-tech manufacturing (d) & 0.17 & 0.38 & 0 & 1 \\
\hline Medium-low-tech manufacturing (d) & 0.16 & 0.37 & 0 & 1 \\
\hline Low-tech manufacturing (d) & 0.20 & 0.40 & 0 & 1 \\
\hline Knowledge-intensive services (d) & 0.28 & 0.45 & 0 & 1 \\
\hline Other services (d) & 0.08 & 0.27 & 0 & 1 \\
\hline
\end{tabular}

(d): dummy variables

Table 2: Off-shoring of innovation by R\&D activity and firm size

\begin{tabular}{lccc}
\hline Share of off-shored innovation & With internal R\&D & No internal R\&D & Total \\
\hline $0 \%$ & 49.5 & 78.5 & 59.7 \\
$>0 \%$ to $5 \%$ & 25.4 & 13.9 & 21.0 \\
$>5 \%$ to $10 \%$ & 12.5 & 5.1 & 10.1 \\
$>10 \%$ to $25 \%$ & 9.7 & 2.5 & 6.9 \\
$>25 \%$ to $50 \%$ & 2.5 & 0.0 & 1.8 \\
$>50 \%$ & 0.4 & 0.0 & 0.5 \\
\hline Share of off-shored innovation & $500+$ employees & $<500$ employees & Total \\
\hline $0 \%$ & 43.3 & 62.6 & 59.7 \\
$>0 \%$ to $5 \%$ & 19.4 & 21.3 & 21.0 \\
$>5 \%$ to $10 \%$ & 10.4 & 10.0 & 10.1 \\
$>10 \%$ to $25 \%$ & 19.4 & 4.8 & 6.9 \\
$>25 \%$ to $50 \%$ & 7.5 & 0.8 & 1.8 \\
$>50 \%$ & 0.0 & 0.5 & 0.5 \\
\hline
\end{tabular}


Not surprisingly, we find that the propensity to off-shore innovation is a higher for firms with internal R\&D. More than half of $R \& D$ performing firms have off-shored at least some parts of their innovation activities. This shows that off-shoring of knowledgeintensive processes has become very common. However, most firms still conduct the majority of $R \& D$ at on-shore sites. Only about $13 \%$ of $R \& D$ performers have relocated more than $10 \%$ of their innovation activities. Virtually none have conducted more than $50 \%$ non-domestically. While the propensity to off-shore is much lower for firms without internal $R \& D$, the interesting observation is that still $7 \%$ of non-R\&D performer had off-shored some innovation activities, particularly design and downstream activities. This also shows that internal R\&D, even if an important driver, is not a necessary condition for off-shoring innovation.

Concerning size, we find that larger firms (500 or more employees) are more likely to off-shore than smaller ones. About $20 \%$ of the small and medium sized companies have off-shored some innovation-related activities compared to $45 \%$ for larger firms.

Table 3: Off-shoring of innovation by sector grouping

\begin{tabular}{lrrrrrr}
\hline & $0 \%$ & $>0 \%$ to & $>5 \%$ to & $>10 \%$ to & $>25 \%$ to & $>50 \%$ \\
Sector & & $5 \%$ & $10 \%$ & $25 \%$ & $50 \%$ & \\
\hline High-tech & 38.6 & 27.3 & 18.2 & 11.4 & 4.5 & 0.0 \\
Medium-high-tech & 38.9 & 26.4 & 20.8 & 8.3 & 4.2 & 1.4 \\
Medium-low-tech & 53.9 & 27.9 & 9.2 & 7.9 & 1.1 & 0.0 \\
Low-tech & 60.6 & 23.4 & 8.5 & 7.5 & 0.0 & 0.0 \\
Knowledge-intensive services & 77.6 & 13.6 & 4.8 & 3.2 & 0.8 & 0.0 \\
Other services & 75.0 & 8.3 & 2.8 & 8.3 & 2.8 & 2.8 \\
\hline
\end{tabular}

With respect to the technology level of sectors we find a consistent picture for manufacturing. The higher the technology level, the higher is also the propensity to offshore innovation. In the service sectors, knowledge-intensive services show a somewhat lower propensity for innovation off-shoring than other services. Compared to manufacturing, off-shoring activities in services are significantly lower which can be related to the higher complexity of geographically decomposing service processes. In addition, size effects are likely to determine sector patterns too, since service firms in our sample are smaller than manufacturing firms

\subsection{Investigation of Hypotheses}

In $\mathrm{H} 1$ we hypothesized that firms experience an inverted u-shape relationship, basically firms should try to create ND-processes. This means that firms that do not decompose decomposable processes (too little $R \& D$ off-shoring) show a lower ability to introduce organizational innovation, while the same adverse effects should hold for firms that do too much R\&D off-shoring. 
We test this hypothesis by regressing the share of off-shored innovation and its square on the success with organizational innovation. We differentiate between different types of R\&D. Namely: the share of off-shored internal $R \& D$, the share of off-shored design, and the share of off-shored downstream activities, among them the sale of new products.

The results are summarized in Table 4. Models 1-3 differ from Models 4-6 because the latter additionally control for past off-shoring activities and the off-shoring proximity. In the first three models we find our hypothesis of an inverted u-shape strongly confirmed for all three types of off-shored innovation. When we additionally control for learning and off-shoring proximity the u-shape remains for construction and design activities as well as downstream. For internal $R \& D$, however, while both the linear and the squared terms have the expected sign, they are not significant anymore. This suggests that the u-shape disappears in this case. However, if we run the regressions the internal R\&D by type of effect of organizational innovation we find a significant inverted u-shape for reaction times, production costs, and communication flows. All effects (both linear and squared) are insignificant for development capabilities and quality. This supports the view that also for internal $R \& D$ the relationship is quadratic but not for all effect-dimensions and corroborates the inverse u-shape for design as well as downstream activities generally but also for internal $R \& D$ with respect to specific organizational effects.

With respect to the confounding factors we see that size does not have a significant influence on organizational adaptability. The same seems to be true for export activities, with the exception of Model 1 where we find a weakly significantly positive impact. On the contrary, the dummy for the presence of past off-shoring activities is clearly positive which gives a strong indication of the existence of management learning effects as hypothesized. The dummy for the group membership is also significantly positive which we interpreted as a proxy for experience in organizing multi-site processes. The results with respect to these variables remain relatively stable in all subsequent regressions. Therefore, we will not repeatedly discuss these results in what is to follow.

Having established an inverted u-shape of off-shoring and organizational innovation, an interesting follow-up question is about the optimal level of innovation off-shoring, whether this optimal level differs by type of innovation, and how many firms are above or below that threshold. The results for the first two questions are illustrated in Figure 1.3

3 The optimal value follows easily directly from differentiation yielding optval $=-\beta_{l} /\left(2 \beta_{s q}\right)$, with $\beta$ denoting the coefficient of the linear and the squared value for the share of off-shored innovation activities. 
Table 4: Innovation Off-shoring and Organizational Adaptability

\begin{tabular}{|c|c|c|c|c|c|c|}
\hline & $\begin{array}{c}\text { (1) } \\
\text { OA: } \\
\text { General }\end{array}$ & $\begin{array}{c}\text { (2) } \\
\text { OA: } \\
\text { General }\end{array}$ & $\begin{array}{c}\text { (3) } \\
\text { OA: } \\
\text { General }\end{array}$ & $\begin{array}{c}\text { (4) } \\
\text { OA: } \\
\text { General }\end{array}$ & $\begin{array}{c}\text { (5) } \\
\text { OA: } \\
\text { General }\end{array}$ & $\begin{array}{c}\text { (6) } \\
\text { OA: } \\
\text { General }\end{array}$ \\
\hline Share off-shored R\&D & $\begin{array}{l}0.15367 * * \\
(2.52)\end{array}$ & & & $\begin{array}{c}0.09366 \\
(1.44)\end{array}$ & & \\
\hline (Share off-shored & -0.00047 & & & -0.00045 & & \\
\hline R\&D)*(Relative dispersion) & $(-1.34)$ & & & $(-1.29)$ & & \\
\hline$($ Share off-shored R\&D)^2 & $\begin{array}{c}-0.00404^{* *} \\
(-2.06)\end{array}$ & & & $\begin{array}{c}-0.00223 \\
(-1.07)\end{array}$ & & \\
\hline Share off-shored design & & $\begin{array}{l}0.07922 * * \\
(2.28)\end{array}$ & & & $\begin{array}{c}0.06065^{*} \\
(1.71)\end{array}$ & \\
\hline (Share off-shored & & -0.00019 & & & -0.00013 & \\
\hline design)*(Relative dispersion) & & $(-0.56)$ & & & $(-0.38)$ & \\
\hline$(\text { Share off-shored design })^{\wedge} 2$ & & $\begin{array}{c}-0.00083^{* *} \\
(-2.00)\end{array}$ & & & $\begin{array}{c}-0.00070^{*} \\
(-1.65)\end{array}$ & \\
\hline $\begin{array}{l}\text { Share off-shored downstream } \\
\text { activities }\end{array}$ & & & $\begin{array}{l}0.12494 * * * \\
\quad(3.26)\end{array}$ & & & $\begin{array}{l}0.10326 * * * \\
\quad(2.58)\end{array}$ \\
\hline $\begin{array}{l}\text { (Share off-shored downstream } \\
\text { activities)*(Relative dispersion) }\end{array}$ & & & $\begin{array}{c}-0.00053^{* *} \\
(-2.39)\end{array}$ & & & $\begin{array}{c}-0.00051^{* *} \\
(-2.21)\end{array}$ \\
\hline $\begin{array}{l}\text { (Share off-shored downstream } \\
\text { activities)^2 }\end{array}$ & & & $\begin{array}{c}-0.00227 * * \\
(-2.47)\end{array}$ & & & $\begin{array}{c}-0.00184 * * \\
(-1.99)\end{array}$ \\
\hline Market share & $\begin{array}{c}0.34693 \\
(1.30)\end{array}$ & $\begin{array}{c}0.40114 \\
(1.46)\end{array}$ & $\begin{array}{c}0.41050 \\
(1.50)\end{array}$ & $\begin{array}{c}0.37134 \\
(1.39)\end{array}$ & $\begin{array}{c}0.39069 \\
(1.41)\end{array}$ & $\begin{array}{c}0.38044 \\
(1.38)\end{array}$ \\
\hline Share material costs & $\begin{array}{c}0.25528 \\
(0.79)\end{array}$ & $\begin{array}{c}0.06421 \\
(0.19)\end{array}$ & $\begin{array}{c}0.20704 \\
(0.62)\end{array}$ & $\begin{array}{c}0.22213 \\
(0.68)\end{array}$ & $\begin{array}{c}0.03379 \\
(0.10)\end{array}$ & $\begin{array}{c}0.15528 \\
(0.46)\end{array}$ \\
\hline Employees (FTE) & $\begin{array}{c}-0.00001 \\
(-0.33)\end{array}$ & $\begin{array}{c}-0.00003 \\
(-1.00)\end{array}$ & $\begin{array}{c}-0.00003 \\
(-0.71)\end{array}$ & $\begin{array}{c}-0.00001 \\
(-0.50)\end{array}$ & $\begin{array}{c}-0.00003 \\
(-1.19)\end{array}$ & $\begin{array}{c}-0.00004 \\
(-0.89)\end{array}$ \\
\hline$(\text { Employees }(\mathrm{FTE}))^{\wedge}$ & $\begin{array}{c}0.00000 \\
(0.58)\end{array}$ & $\begin{array}{c}0.00000 \\
(0.92)\end{array}$ & $\begin{array}{c}0.00000 \\
(0.83)\end{array}$ & $\begin{array}{c}0.00000 \\
(0.72)\end{array}$ & $\begin{array}{c}0.00000 \\
(1.13)\end{array}$ & $\begin{array}{c}0.00000 \\
(0.99)\end{array}$ \\
\hline Export intensity & $\begin{array}{c}0.28972 \\
(0.91)\end{array}$ & $\begin{array}{c}0.27933 \\
(0.85)\end{array}$ & $\begin{array}{c}0.16848 \\
(0.46)\end{array}$ & $\begin{array}{c}0.05071 \\
(0.15)\end{array}$ & $\begin{array}{c}0.04630 \\
(0.14)\end{array}$ & $\begin{array}{c}0.02616 \\
(0.07)\end{array}$ \\
\hline $\mathrm{R} \& \mathrm{D}$ intensity & $\begin{array}{c}0.21074 \\
(0.34)\end{array}$ & $\begin{array}{c}-0.21761 \\
(-0.37)\end{array}$ & $\begin{array}{c}0.06185 \\
(0.11)\end{array}$ & $\begin{array}{c}0.35869 \\
(0.58)\end{array}$ & $\begin{array}{c}-0.05048 \\
(-0.09)\end{array}$ & $\begin{array}{c}0.13510 \\
(0.24)\end{array}$ \\
\hline Eastern Germany & $\begin{array}{c}0.19477 \\
(1.30)\end{array}$ & $\begin{array}{c}0.18141 \\
(1.18)\end{array}$ & $\begin{array}{c}0.18141 \\
(1.17)\end{array}$ & $\begin{array}{c}0.24574 \\
(1.63)\end{array}$ & $\begin{array}{c}0.25126 \\
(1.60)\end{array}$ & $\begin{array}{c}0.23977 \\
(1.53)\end{array}$ \\
\hline Group member & $\begin{array}{c}0.26632^{*} \\
(1.83)\end{array}$ & $\begin{array}{l}0.40948^{* * *} \\
\quad(2.74)\end{array}$ & $\begin{array}{l}0.30604^{* *} \\
(2.06)\end{array}$ & $\begin{array}{c}0.25261^{*} \\
(1.72)\end{array}$ & $\begin{array}{l}0.36628^{* *} \\
(2.41)\end{array}$ & $\begin{array}{c}0.27398^{*} \\
(1.81)\end{array}$ \\
\hline Off-shoring in 2005 & & & & $\begin{array}{l}0.50738^{* * *} \\
\quad(2.63)\end{array}$ & $\begin{array}{l}0.54296 * * * \\
\quad(2.71)\end{array}$ & $\begin{array}{l}0.55039 * * * \\
(2.70)\end{array}$ \\
\hline Off-shoring proximity & & & & $\begin{array}{c}0.04033 \\
(0.41)\end{array}$ & $\begin{array}{c}0.03541 \\
(0.35)\end{array}$ & $\begin{array}{c}0.05425 \\
(0.54)\end{array}$ \\
\hline $\begin{array}{l}\text { Medium-high-tech } \\
\text { manufacturing }\end{array}$ & $\begin{array}{c}0.07704 \\
(0.26)\end{array}$ & $\begin{array}{c}0.18126 \\
(0.60)\end{array}$ & $\begin{array}{c}0.13421 \\
(0.46)\end{array}$ & $\begin{array}{c}0.10461 \\
(0.35)\end{array}$ & $\begin{array}{c}0.16060 \\
(0.53)\end{array}$ & $\begin{array}{c}0.13312 \\
(0.45)\end{array}$ \\
\hline $\begin{array}{l}\text { Medium-low-tech } \\
\text { manufacturing }\end{array}$ & $\begin{array}{c}0.12442 \\
(0.43)\end{array}$ & $\begin{array}{c}0.38828 \\
(1.29)\end{array}$ & $\begin{array}{c}0.32691 \\
(1.12)\end{array}$ & $\begin{array}{c}0.13650 \\
(0.47)\end{array}$ & $\begin{array}{c}0.33663 \\
(1.11)\end{array}$ & $\begin{array}{c}0.28176 \\
(0.96)\end{array}$ \\
\hline Low-tech manufacturing & $\begin{array}{c}-0.01863 \\
(-0.06)\end{array}$ & $\begin{array}{c}0.09555 \\
(0.32)\end{array}$ & $\begin{array}{c}0.11802 \\
(0.40)\end{array}$ & $\begin{array}{c}0.00440 \\
(0.02)\end{array}$ & $\begin{array}{c}0.08852 \\
(0.29)\end{array}$ & $\begin{array}{c}0.12013 \\
(0.41)\end{array}$ \\
\hline Knowledge-intensive services & $\begin{array}{c}0.44269 \\
(1.53)\end{array}$ & $\begin{array}{c}0.56408^{*} \\
(1.86)\end{array}$ & $\begin{array}{l}0.65093^{* *} \\
(2.19)\end{array}$ & $\begin{array}{c}0.47468 \\
(1.63)\end{array}$ & $\begin{array}{c}0.57800^{*} \\
(1.91)\end{array}$ & $\begin{array}{l}0.65529 * * \\
(2.20)\end{array}$ \\
\hline Other services & $\begin{array}{c}0.26956 \\
(0.71)\end{array}$ & $\begin{array}{c}0.35161 \\
(0.89)\end{array}$ & $\begin{array}{c}0.49045 \\
(1.26)\end{array}$ & $\begin{array}{c}0.27088 \\
(0.71)\end{array}$ & $\begin{array}{c}0.35202 \\
(0.89)\end{array}$ & $\begin{array}{c}0.48425 \\
(1.23)\end{array}$ \\
\hline Observations & 277 & 261 & 261 & 277 & 261 & 261 \\
\hline Pseudo $R^{2}$ & 0.021 & 0.027 & 0.029 & 0.027 & 0.035 & 0.037 \\
\hline AIC & 1134.87 & 1052.47 & 1055.96 & 1131.55 & 1048.85 & 1052.19 \\
\hline
\end{tabular}

t statistics in parentheses; ${ }^{*} \mathrm{p}<0.10,{ }^{* *} \mathrm{p}<0.05,{ }^{* * *} \mathrm{p}<0.01$ 
Figure 1: Threshold values for Innovation Off-shoring by Type

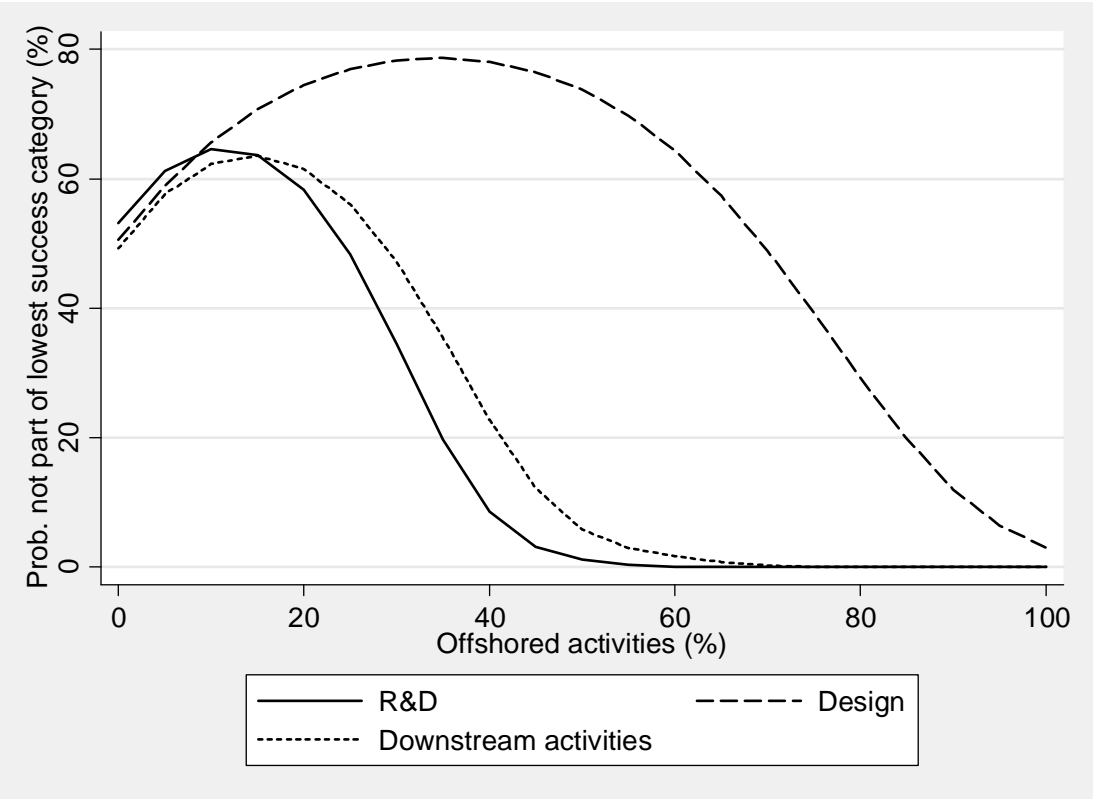

The results strongly show that the optimal threshold is highest for design (31.13\%) and much lower for R\&D (11.84\%) and downstream activities (14.79\%). This clearly corroborates H1b.

The optimal threshold implies that there is a possibility of over-off-shoring. The question then becomes how prevalent this phenomenon is. With respect to all firms including the non-off-shorers it seems limited, because over 95\% stay below this threshold. The picture, however, is different when we focus on the share of firms above the respective thresholds among the off-shorers. While the figures are with $6.89 \%$ still quite low in the case of construction and design, they are larger for downstream activities (19.61\%) and massive for internal R\&D (almost 40\%). This means that, if firms off-shore internal $\mathrm{R} \& \mathrm{D}$, a large share goes beyond the threshold. These companies run the risk of experiencing problems of organizational integration.

Table 5: Over-off-shorers by innovation type

\begin{tabular}{|c|c|c|c|c|}
\hline & Optimal value & z-value & Larger values & Larger values \\
\hline & $(\%)$ & & total (\%) & off-shorers (\%) \\
\hline Share of off-shored internal R\&D & $11.18 * * *$ & 2.24 & 4.3 & 38.2 \\
\hline Share of off-shored design & $34.49 * * *$ & 8.7 & 0.7 & 4.9 \\
\hline Share of off-shored downstream activities & $14.49 * * *$ & 4.73 & 8.0 & 19.9 \\
\hline
\end{tabular}

*** $p<0.01$

The optimal threshold implies that there is a possibility of over-off-shoring. The question then becomes how prevalent this phenomenon is. With respect to all firms including the non-off-shorers it seems limited, because over 95\% stay below this threshold. The picture, however, is different when we focus on the share of firms above 
the respective thresholds among the off-shorers. While the figures are with $6.89 \%$ still quite low in the case of construction and design, they are larger for downstream activities (19.61\%) and massive for internal R\&D (almost 40\%). This means that, if firms off-shore internal R\&D, a large share goes beyond the threshold. These companies run the risk of experiencing problems of organizational integration.

Turning to the question of possible moderators H2a argued that geographical dispersion amplifies the costs of off-shoring leading for any level of off-shoring to lower optimal thresholds.

Concerning H2a we indeed find that the interaction effects with the measure for relative dispersion is negative for all categories in Table 4. However, it is significant only for the off-shored downstream activities. In this case the optimal threshold is lower the higher the geographical dispersion is. Therefore, we can corroborate H2a but only with respect to the downstream activities.

Turning to the question of possible moderators we have suggested in H2b that smaller firms find it easier to deal with geographical dispersion because of lower combinatorial complexity of smaller systems. In fact, what we do find in Model 1 in Table 6 is that the coefficient on the moderation effect with an indicator for large companies is negative, while the main effect is insignificant. This implies that larger firms suffer more severely from increasing geographical dispersion of their R\&D process. This clearly gives more evidence of $\mathrm{H} 2 \mathrm{~b}$.

In addition to size, we have hypothesized in $\mathrm{H} 3$ that off-shoring innovation might generate problems for firms that are strongly involved in local innovation collaborations. This is because innovation has increasingly become a collaborative and open process which is often taking place in networks. Off-shoring then implies that local network participation might be weakened because they receive less attention.

If this was true, we would expect a negative coefficient for the interaction term of the share of off-shored innovation activities and the number of different types of local collaboration partners in innovation. In Table 6 we analyze this effect for each type of innovation activity. We find the effect is corroborated for R\&D and design. The coefficient for downstream activities has the predicted negative sign but fails to reach the significance level. Therefore, we can confirm H3 for R\&D and design only.

It is noteworthy that the effect from the degree of remoteness from local innovation networks seems to become stronger from $R \& D$ over design to downstream investment as the coefficient becomes more negative and more significant. This is an intuitive observation because collaborative development of innovation should be more compelling for core $\mathrm{R} \& \mathrm{D}$ activities in comparison to more remote downstream activities. 
Table 6: Interaction of cooperation and geographical dispersion as moderators of innovation off-shoring impacts on organizational adaptability: results of orderd Probit models

\begin{tabular}{|c|c|c|c|c|}
\hline & $\begin{array}{c}\text { (1) } \\
\text { OA: } \\
\text { General }\end{array}$ & $\begin{array}{c}\text { (2) } \\
\text { OA: } \\
\text { General }\end{array}$ & $\begin{array}{c}\text { (3) } \\
\text { OA: } \\
\text { General }\end{array}$ & $\begin{array}{c}\text { (4) } \\
\text { OA: } \\
\text { General }\end{array}$ \\
\hline \# types domestic R\&D partners & & $\begin{array}{l}0.19898 * * * \\
(3.30)\end{array}$ & $\begin{array}{l}0.17754 * * * \\
(3.04)\end{array}$ & $\begin{array}{l}0.18152 * * * \\
\quad(2.81)\end{array}$ \\
\hline $\begin{array}{l}\text { (Share off-shored } \mathrm{R} \& \mathrm{D}) *(\# \text { types domestic } \mathrm{R} \& \mathrm{D} \\
\text { partners) }\end{array}$ & & $\begin{array}{c}-0.03141 * * \\
(-2.27)\end{array}$ & & \\
\hline $\begin{array}{l}\text { (Share off-shored design)*(\# types domestic R\&D } \\
\text { partners) }\end{array}$ & & & $\begin{array}{c}-0.01021^{*} \\
(-1.83)\end{array}$ & \\
\hline $\begin{array}{l}\text { (Share off-shored downstream activities)*(\# types } \\
\text { domestic R\&D partners) }\end{array}$ & & & & $\begin{array}{c}-0.00625 \\
(-0.93)\end{array}$ \\
\hline Relative geographical dispersion & $\begin{array}{c}0.00711 \\
(1.25)\end{array}$ & & & \\
\hline Large company & $\begin{array}{l}1.87582 * * \\
(2.50)\end{array}$ & & & \\
\hline (Relative dispersion)*(Large company) & $\begin{array}{c}-0.02182^{* * *} \\
(-2.85)\end{array}$ & & & \\
\hline Market share & $\begin{array}{c}0.32501 \\
(1.17)\end{array}$ & $\begin{array}{c}0.22872 \\
(0.79)\end{array}$ & $\begin{array}{c}0.26470 \\
(0.92)\end{array}$ & $\begin{array}{c}0.26544 \\
(0.92)\end{array}$ \\
\hline Share material costs & $\begin{array}{c}0.01547 \\
(0.05)\end{array}$ & $\begin{array}{c}0.07461 \\
(0.22)\end{array}$ & $\begin{array}{c}0.05982 \\
(0.17)\end{array}$ & $\begin{array}{c}0.06867 \\
(0.20)\end{array}$ \\
\hline Employees (FTE) & $\begin{array}{c}-0.00004 \\
(-0.99)\end{array}$ & $\begin{array}{c}-0.00003 \\
(-1.05)\end{array}$ & $\begin{array}{c}-0.00003 \\
(-0.90)\end{array}$ & $\begin{array}{c}-0.00002 \\
(-0.56)\end{array}$ \\
\hline$(\text { Employees }(\mathrm{FTE}))^{\wedge} 2$ & $\begin{array}{c}0.00000 \\
(1.12)\end{array}$ & $\begin{array}{l}0.00000^{*} \\
(1.65)\end{array}$ & $\begin{array}{c}0.00000 \\
(1.07)\end{array}$ & $\begin{array}{c}0.00000 \\
(0.70)\end{array}$ \\
\hline Export intensity & $\begin{array}{c}0.22830 \\
(0.61)\end{array}$ & $\begin{array}{c}0.06994 \\
(0.19)\end{array}$ & $\begin{array}{c}0.04375 \\
(0.12)\end{array}$ & $\begin{array}{c}0.11121 \\
(0.30)\end{array}$ \\
\hline R\&D intensity & $\begin{array}{c}0.29326 \\
(0.46)\end{array}$ & $\begin{array}{c}0.37019 \\
(0.56)\end{array}$ & $\begin{array}{c}0.02975 \\
(0.05)\end{array}$ & $\begin{array}{c}0.00512 \\
(0.01)\end{array}$ \\
\hline Eastern Germany & $\begin{array}{c}0.20898 \\
(1.33)\end{array}$ & $\begin{array}{c}0.22607 \\
(1.43)\end{array}$ & $\begin{array}{c}0.23460 \\
(1.48)\end{array}$ & $\begin{array}{c}0.21194 \\
(1.34)\end{array}$ \\
\hline Group member & $\begin{array}{c}0.42022^{* * *} \\
(2.62)\end{array}$ & $\begin{array}{c}0.31479 * * \\
(1.99)\end{array}$ & $\begin{array}{c}0.33185^{* *} \\
(2.08)\end{array}$ & $\begin{array}{c}0.31096 * \\
(1.95)\end{array}$ \\
\hline Share off-shored R\&D & $\begin{array}{c}-0.02917 \\
(-1.61)\end{array}$ & $\begin{array}{c}0.02973 \\
(0.97)\end{array}$ & $\begin{array}{c}-0.02058 \\
(-1.15)\end{array}$ & $\begin{array}{c}-0.02635 \\
(-1.49)\end{array}$ \\
\hline Share off-shored construction \& design & $\begin{array}{c}0.02273^{*} \\
(1.84)\end{array}$ & $\begin{array}{c}0.03473^{* *} \\
(2.36)\end{array}$ & $\begin{array}{c}0.03982^{* *} \\
(2.30)\end{array}$ & $\begin{array}{c}0.02040 \\
(1.61)\end{array}$ \\
\hline Share off-shored downstream activities & $\begin{array}{c}-0.00152 \\
(-0.12)\end{array}$ & $\begin{array}{c}-0.00138 \\
(-0.11)\end{array}$ & $\begin{array}{c}0.00134 \\
(0.11)\end{array}$ & $\begin{array}{c}0.00831 \\
(0.61)\end{array}$ \\
\hline Off-shoring proximity & $\begin{array}{c}0.04734 \\
(0.46)\end{array}$ & $\begin{array}{c}0.05455 \\
(0.52)\end{array}$ & $\begin{array}{c}0.04728 \\
(0.45)\end{array}$ & $\begin{array}{c}0.05021 \\
(0.48)\end{array}$ \\
\hline Off-shoring in 2005 & $\begin{array}{l}0.53245^{* *} \\
(2.56)\end{array}$ & $\begin{array}{c}0.53956^{* * *} \\
(2.60)\end{array}$ & $\begin{array}{l}0.53854^{* * * *} \\
(2.60)\end{array}$ & $\begin{array}{c}0.54526^{* * *} \\
(2.63)\end{array}$ \\
\hline Medium-high-tech manufacturing & $\begin{array}{c}0.19761 \\
(0.65)\end{array}$ & $\begin{array}{c}0.03145 \\
(0.10)\end{array}$ & $\begin{array}{c}0.08779 \\
(0.29)\end{array}$ & $\begin{array}{c}0.02387 \\
(0.08)\end{array}$ \\
\hline Medium-low-tech manufacturing & $\begin{array}{c}0.31872 \\
(1.06)\end{array}$ & $\begin{array}{c}0.29732 \\
(0.98)\end{array}$ & $\begin{array}{c}0.28250 \\
(0.93)\end{array}$ & $\begin{array}{c}0.22636 \\
(0.75)\end{array}$ \\
\hline Low-tech manufacturing & $\begin{array}{c}0.10851 \\
(0.36)\end{array}$ & $\begin{array}{c}0.09030 \\
(0.30)\end{array}$ & $\begin{array}{c}0.05765 \\
(0.19)\end{array}$ & $\begin{array}{c}0.01165 \\
(0.04)\end{array}$ \\
\hline Knowledge-intensive services & $\begin{array}{l}0.59870^{* *} \\
(1.97)\end{array}$ & $\begin{array}{c}0.59321 * \\
(1.94)\end{array}$ & $\begin{array}{c}0.56326^{*} \\
(1.85)\end{array}$ & $\begin{array}{c}0.51928^{*} \\
(1.71)\end{array}$ \\
\hline Other services & $\begin{array}{c}0.38477 \\
(0.97)\end{array}$ & $\begin{array}{c}0.38545 \\
(0.97)\end{array}$ & $\begin{array}{c}0.33956 \\
(0.85) \\
\end{array}$ & $\begin{array}{c}0.35918 \\
(0.90)\end{array}$ \\
\hline Observations & 258 & 253 & 253 & 253 \\
\hline Pseudo $R^{2}$ & 0.043 & 0.045 & 0.043 & 0.040 \\
\hline$A I C$ & 1039.07 & 1013.90 & 1015.83 & 1018.31 \\
\hline
\end{tabular}

$t$ statistics in parentheses; $* p<0.10,{ }^{* *} p<0.05$, ${ }^{* * *} p<0.01$

Finally, it seems commonly agreed that off-shoring is be particularly problematic for organizational adaptability for firms with a strong strategic focus on R\&D. For these 
firms off-shoring could imply a loss of control over certain strategic processes, which is generally assumed to be detrimental. We analyze whether this particular limitation of off-shoring exists by interacting $R \& D$ off-shoring with a firms' $R \& D$ intensity at domestic locations. Differentiating by performance impacts of organizational adaptability we find that a negative interaction effect can only be observed for offshoring impacts on the ability to develop innovations but not for the other effects, among them costs or reaction times (see Table 7).

Table 7: Interaction effect of $R \& D$ off-shoring and $R \& D$ intensity on different performance impacts of organizational adaptability: results of order Probit models

\begin{tabular}{|c|c|c|c|c|c|}
\hline & $\begin{array}{c}\text { (1) } \\
\text { OA: } \\
\text { Reaction } \\
\text { time }\end{array}$ & $\begin{array}{c}\text { (2) } \\
\text { OA: } \\
\text { Develop- } \\
\text { ment } \\
\text { capability }\end{array}$ & $\begin{array}{c}\text { (3) } \\
\text { OA: } \\
\text { Quality }\end{array}$ & $\begin{array}{c}\text { (4) } \\
\text { OA: } \\
\text { Produc- } \\
\text { tion costs }\end{array}$ & $\begin{array}{c}\text { (5) } \\
\text { OA: } \\
\text { Commu- } \\
\text { nication }\end{array}$ \\
\hline Share off-shored R\&D & $\begin{array}{c}-0.00997 \\
(-0.50)\end{array}$ & $\begin{array}{c}-0.00488 \\
(-0.24)\end{array}$ & $\begin{array}{c}-0.01855 \\
(-0.92)\end{array}$ & $\begin{array}{c}-0.01046 \\
(-0.51)\end{array}$ & $\begin{array}{c}-0.01840 \\
(-0.91)\end{array}$ \\
\hline Share off-shored design & $\begin{array}{c}0.01111 \\
(0.88)\end{array}$ & $\begin{array}{c}0.02262 * \\
(1.79)\end{array}$ & $\begin{array}{c}0.01943 \\
(1.46)\end{array}$ & $\begin{array}{c}0.00641 \\
(0.50)\end{array}$ & $\begin{array}{c}0.03024^{* *} \\
(2.36)\end{array}$ \\
\hline Share off-shored downstream activities & $\begin{array}{c}0.00501 \\
(0.39)\end{array}$ & $\begin{array}{c}0.00339 \\
(0.26)\end{array}$ & $\begin{array}{c}-0.00494 \\
(-0.37)\end{array}$ & $\begin{array}{c}0.00040 \\
(0.03)\end{array}$ & $\begin{array}{c}-0.00150 \\
(-0.11)\end{array}$ \\
\hline Market share & $\begin{array}{c}0.30575 \\
(1.05)\end{array}$ & $\begin{array}{c}0.34390 \\
(1.16)\end{array}$ & $\begin{array}{c}0.28252 \\
(0.98)\end{array}$ & $\begin{array}{c}0.31721 \\
(1.09)\end{array}$ & $\begin{array}{c}0.19807 \\
(0.69)\end{array}$ \\
\hline Employees (FTE) & $\begin{array}{c}-0.00003 \\
(-0.86)\end{array}$ & $\begin{array}{c}-0.00003 \\
(-0.98)\end{array}$ & $\begin{array}{c}-0.00003 \\
(-0.76)\end{array}$ & $\begin{array}{c}-0.00002 \\
(-0.79)\end{array}$ & $\begin{array}{c}-0.00002 \\
(-0.72)\end{array}$ \\
\hline$(\text { Employees }(\mathrm{FTE}))^{\wedge} 2$ & $\begin{array}{c}0.00000 \\
(0.86)\end{array}$ & $\begin{array}{c}0.00000 \\
(1.19)\end{array}$ & $\begin{array}{c}0.00000 \\
(0.81)\end{array}$ & $\begin{array}{c}0.00000 \\
(0.84)\end{array}$ & $\begin{array}{c}0.00000 \\
(0.70)\end{array}$ \\
\hline Export intensity & $\begin{array}{c}0.16864 \\
(0.44)\end{array}$ & $\begin{array}{c}0.29412 \\
(0.76)\end{array}$ & $\begin{array}{c}0.29406 \\
(0.76)\end{array}$ & $\begin{array}{c}0.33219 \\
(0.86)\end{array}$ & $\begin{array}{c}0.28181 \\
(0.74)\end{array}$ \\
\hline R\&D intensity & $\begin{array}{c}0.68899 \\
(0.84)\end{array}$ & $\begin{array}{c}3.26468 * * \\
(2.08)\end{array}$ & $\begin{array}{c}0.42264 \\
(0.51)\end{array}$ & $\begin{array}{c}0.09990 \\
(0.12)\end{array}$ & $\begin{array}{c}0.82396 \\
(1.01)\end{array}$ \\
\hline Eastern Germany & $\begin{array}{c}0.21811 \\
(1.34)\end{array}$ & $\begin{array}{c}0.28291 * \\
(1.68)\end{array}$ & $\begin{array}{c}0.21962 \\
(1.34)\end{array}$ & $\begin{array}{c}0.29189 * \\
(1.78)\end{array}$ & $\begin{array}{c}0.25759 \\
(1.59)\end{array}$ \\
\hline Medium-low-tech manufacturing & $\begin{array}{c}0.17633 \\
(0.57)\end{array}$ & $\begin{array}{c}0.02654 \\
(0.08)\end{array}$ & $\begin{array}{c}0.13520 \\
(0.44)\end{array}$ & $\begin{array}{c}0.29496 \\
(0.96)\end{array}$ & $\begin{array}{c}0.39655 \\
(1.27)\end{array}$ \\
\hline Low-tech manufacturing & $\begin{array}{c}-0.04878 \\
(-0.16)\end{array}$ & $\begin{array}{c}-0.13221 \\
(-0.41)\end{array}$ & $\begin{array}{c}-0.09655 \\
(-0.31)\end{array}$ & $\begin{array}{c}-0.04499 \\
(-0.15)\end{array}$ & $\begin{array}{c}0.36688 \\
(1.17)\end{array}$ \\
\hline Knowledge-intensive services & $\begin{array}{c}0.62443^{* *} \\
(2.03)\end{array}$ & $\begin{array}{c}0.42053 \\
(1.32)\end{array}$ & $\begin{array}{c}0.59899 * \\
(1.95)\end{array}$ & $\begin{array}{c}0.19783 \\
(0.64)\end{array}$ & $\begin{array}{c}0.67830 * * \\
(2.17)\end{array}$ \\
\hline Other services & $\begin{array}{c}0.31277 \\
(0.77)\end{array}$ & $\begin{array}{c}0.18798 \\
(0.45)\end{array}$ & $\begin{array}{c}0.28830 \\
(0.71)\end{array}$ & $\begin{array}{c}0.48955 \\
(1.21)\end{array}$ & $\begin{array}{c}0.61454 \\
(1.49)\end{array}$ \\
\hline Observations & 258 & 258 & 258 & 258 & 258 \\
\hline Pseudo $R^{2}$ & 0.042 & 0.080 & 0.047 & 0.054 & 0.043 \\
\hline AIC & 632.1 & 585.15 & 637.44 & 604.97 & 636.61 \\
\hline
\end{tabular}


This result highlights that negative effects of off-shoring in R\&D-intensive firms relate to their core competitive activity, i.e. being able to develop new products and processes. Negative effects are organizationally localized in the sense that off-shoring $R \& D$ negatively affects organizational adaptability of the development process itself but not necessarily the broader organizational adaptability of the firm. $\mathrm{H} 4$ can hence be corroborated for this special case only.

\section{$5 \quad$ Discussion}

We believe that our empirical results provide implications both for management literature and managerial practice in firms. We focus the discussion on three issues: the cost of off-shoring innovation activities, the type of innovation activity that is being offshored, and the link between size and organizational complexity.

While the off-shoring literature has often been relatively enthusiastic about the associated benefits, the cost side has often been ignored or only marginally touched. Only recently it has been highlighted that there are substantial costs associated with offshoring and that these are consistently underestimated by management (Dibbern et al., 2008; Stringfellow et al., 2008; Larsen et al., 2013). Our analysis builds on this finding and identifies not only positive but also negative effects of off-shoring. We show that there seems to be a level of off-shoring of innovation activities beyond which the ability to implement organizational changes effectively decreases.

The strong emphasis on the benefits of off-shoring in the existing literature can be linked to the role that agency problems played as a motivator of costs in the analysis of outsourcing activities. For off-shoring these opportunism-related costs may be weaker because the activities still take place within the boundary of the firm. However, our theoretical approach highlighted that a premature dismissal of the importance of the cost side neglects the fact that off-shoring increases management complexity, particularly with regard to the management of knowledge generation processes. In terms of the knowledge perspective of the firm (Kogut and Zander, 1992; Grant, 1996), excessive off-shoring weakens the knowledge-integration capacities of firms. Our findings hence imply a trade-off between global knowledge sourcing and a firm's ability to use this knowledge effectively. The empirical results suggest that off-shoring more than 15 to $30 \%$ (depending on the type of innovation) of a firm's innovation activities becomes challenging for maintaining the effectiveness of the organization.

The trade-off between benefits and costs also provides a framework for analyzing backshoring activities which has gained in importance recently. The existing literature on this topic mainly investigated back-shoring of production activities and identified a loss of flexibility as well as quality problems as major motives for back-shoring (Kinkel and Maloca, 2009; Kinkel, 2012). The reasons for back-shoring of innovation activities may be quite different from the motives to back-shore manufacturing activities and may 
relate rather to managing knowledge generation and exchange and thus possess a distinct flavor of complexity considerations.

The literature on internationalization of firm activities both through out-sourcing and off-shoring highlighted a considerable diversity of motives, commonly distinguishing market-driven, technology-driven and knowledge-driven motives for R\&D activities (e.g. von Zedtwitz and Gassmann, 2002; Kuemmerle, 1999; Patel and Vega, 1999). Linked to the variety of motives, there is also a variety of firm activities being subject to internationalization. With regard to innovation, our results show that off-shoring of different types of innovation activities has different implications on organizational adaptability. The threshold level is lower for innovation activities that are more closely related to core functions of the firm, i.e. $R \& D$ and marketing of innovation. If a substantial part of these activities take place at firm locations abroad, coordination costs increase and organizational changes become more complex. In case of R\&D offshoring, our results show that organizational adaptability diminishes with respect to responding quickly to changes in a firm's environment, communicating effectively within the organization, and producing goods and services efficiently when the level of R\&D off-shoring amounts to more than $\sim 15 \%$ of total $R \& D$. This low threshold value indicates that keeping most $\mathrm{R} \& \mathrm{D}$ activities at the home base is beneficial in a world where innovation cycles become shorter and developing new technologies more challenging. However, we do not find negative impacts of $R \& D$ off-shoring on organizational processes that are more closely related to innovation, e.g. to keep the quality of products/services high. This result implies that firms aiming to internationalize their R\&D activities beyond that threshold should at the same time invest into their organizational capabilities and put special emphasis on the interfaces between off-shored R\&D and other organizational functions. This is particularly the case for firms that have extensive local innovation networks and that put a strategic focus on R\&D. In addition, managers should avoid too strong geographical dispersion of off-shored innovation activities.

Finally, a dominant pattern in the literature is the claim that larger firms have both higher propensities to off-shore as higher shares of off-shored activities. In many cases, this has led to the assumption that off-shoring is primarily a large-company phenomenon. Although some articles focus on the role of born-globals (e.g. Knight and Cavusgil, 1996) or production off-shoring in SMEs (Di Gregorio et al., 2009), this is particularly evident in the MNE literature (e.g. Bardhan and Jaffe, 2005), which deals mostly with large players. Based on this observation, it seems only a step away from assuming that larger firms are not only more likely to engage in but also organizationally more able to deal with off-shoring. For example, superior management capabilities of larger firms are often invoked as an argument but rarely proven.

Our results show that smaller firms find it easier to deal with the organizational tensions of innovation off-shoring, which we explained by the lower initial complexity 
associated with effective management of smaller firms and higher organizational flexibility. This is in line with a literature that highlights the importance of existing organizational and hierarchical structures of the companies (cf. Hedlund, 1994; Dunning and Lundan, 1998; Kuemmerle, 1999) as a driver for choice of location (Ketokivi and Ali-Yrkkö, 2007). This implies that off-shoring should neither explicitly nor implicitly be understood as a pure large-company phenomenon. Managers of smaller firms with no off-shored innovation activities yet should hence consider the opportunities of offshoring parts of the firm's innovation activity in order to gain from globalization. Our findings imply that many smaller firms have yet managed to internationalize innovation without hurting their competitive advantage of high organizational adaptability.

\section{Conclusions and Lines for Future Research}

This paper investigated the relationship between innovation off-shoring and a firm's ability to effectively introduce organizational change using firm panel data from the German Innovation Survey. Based on complexity theory we developed hypotheses on an inverted u-shape impact of the level of innovation off-shoring on organizational adaptability and how this impact may depend on geographical dispersion of off-shored innovation activities, the extent of a firm's local innovation networks, and a firm's strategic focus on R\&D. In contrast to most of the existing literature on innovation offshoring, we distinguished three types of off-shored innovation activities: R\&D, design, and downstream activities such as producing and marketing of new products. This allows us to investigating the impacts of different off-shoring strategies and deriving more tailored management conclusions.

Our empirical results confirm the expected inverted u-shape for all three types of offshored innovation activities. The threshold levels for an optimum level of innovation outsourcing are lower for R\&D (13\%) and downstream activities (16\%) than for design (38\%). The latter activity often includes adaptation of existing technologies to specific environments in foreign markets and is less closely linked to domestic innovation processes than R\&D or marketing. The inverted u-shape effect of off-shored design and downstream activities holds for all five dimensions of organizational adaptability that were distinguished in this paper (ability to develop new products, improving product/service quality, reducing reaction times, reducing costs, improving communication) while the effect of $R \& D$ is confined to the latter three dimensions.

Geographical dispersion of off-shored innovation activities limits organizational adaptability in larger firms. Firms that are embedded in extensive local innovation networks experience a lower level of organizational adaptability when off-shoring R\&D or design activities. For off-shored downstream innovation activities no significant effect was found. Firms with a strong strategic focus on R\&D tend to suffer in their ability to develop new products when off-shoring $R \& D$. 
The results of our paper shed some new light on role of innovation off-shoring a firm's ability to effectively change organizational processes at its home base. They imply that firms can easily run into a too high level of off-shoring activities which threatens their organizational flexibility and their capacity to effectively react upon changes in their environment. Hence managers need to balance the trade-off between gains from internationalizing innovation (such as access to new knowledge) and drawbacks on organizational adaptability. While this research gave some indication of a likely optimal level of off-shoring for different types of innovation activities, more research is needed on the longer term consequences of very high levels of innovation off-shoring. For instance, it would be particularly interesting to analyze whether it is really the companies that over-off-shore which later back-shore innovation activities since one could argue that off-shoring is a capability which firms learn over time (cf. Anderson et al., 1998), and extensive off-shoring is done primarily by firms which are further on the learning curve. In this view, back-shoring firms may be primarily those that were discouraged by short-term failures.

A main limitation of our research is the lack of analysis on impacts of innovation offshoring on firm performance (e.g. in terms of growth or profitability). While we are confident that organizational adaptability is a critical factor for firm performance, there may be other linkages between off-shoring and firm performance which may counteract likely negative impacts on organizational adaptability, such as increased market power due to globalizing firm activities. Future research should investigate this link more clearly in relating off-shoring to different drivers of firm performance.

Our results on size effects revealed some advantages of SMEs over larger firms when linking off-shoring to the effectiveness of organizational change. Based on our data, we can only speculate on the reasons for this result. More in-depth analyses would be needed on how exactly small firms organize off-shoring activities and how the profit from internationalized innovation. Since most empirical research on innovation offshoring so far focused on larger organizations, much more research on off-shoring in SMEs is needed, including case studies and sector-specific studies. 
Acs, Z.J. and Audretsch, D. (1989), Patents as a Measure of Innovative Activity, Kyklos 42, 171-180.

Aghion, P., Bloom, N., Blundell, R., Griffith, R. and Howitt, P. (2005), Competition and Innovation: An Inverted-U Relationship, Quarterly Journal of Economics 120, 701-728.

Ambos, B. and Ambos, T.C. (2011), Meeting the challenge of offshoring R\&D: an examination of firm- and location-specific factors, $R \& D$ Management 41, 107-119.

Anderson, V., Graham, S. and Lawrence, P. (1998), Learning to internationalize, Journal of Management Development 17, 492-502.

Aoki, M. (1986), Horizontal vs. Vertical Information Structure of the Firm, American Economic Review 76, 971-983.

Aschhoff, B. and Schmidt, T. (2010), Empirical Evidence on the Success of R\&D Cooperation - Happy together? Review of Industrial Organization 33(1), 41-62.

Aulakh, P. and Kotabe, M. (2008), Institutional Changes and Organizational Transformation in Developing Economies, Journal of International Management 14, 209-216.

Bals, L., Ørberg Jensen, P.D., Larsen, M. and Pedersen, T. (2013), Exploring Layers of Complexity, in: Pedersen, T., Bals, L., Ørberg Jensen, P.D., Larsen, M. (eds.): The Offshoring Challenge, Springer, Heidelberg et al., 1-18.

Bardhan, A. and Jaffe, D. (2005), Innovation, R\&D and Offshoring, Fisher Center for Real Estate and Urban Economics, University of California, Berkeley.

Barney, J. (1991), Firm Resources and Sustained Competitive Advantage, Journal of Management 17, 99-120.

Barthélemy, J. and Quélin, B.V. (2006), Complexity of outsourcing contracts and ex post transaction costs: an empirical investigation, Journal of Management Studies 43, 1775-1797.

Bartlett, C.A. and Ghoshal, S. (1998), Managing Across Borders: The Transnational Solution, Harvard Business School Press, Cambridge.

Bettis, R., Bradley, S. and Hamel, G. (1992), Outsourcing and Industrial decline, Academy of Management Executive 6, 7-22.

Birkinshaw, J. and Hood, N. (1998), Multinational corporate evolution and subsidiary development, Macmillan Press, London.

Boehe, D.M. (2007), Product Development in MNC Subsidiaries: Local Linkages and Global Interdependence, Journal of International Management 13(4), 488-512.

Campagnolo, D. and Camuffo, A. (2010), The Concept Of Modularity In Management Studies: A Literature Review, International Journal of Management Reviews 12, 259-283. 
Cassiman, B. and Veugelers, R. (2006), In search of complementarity in the innovation strategy: internal R\&D and external knowledge acquisition, Management Science 52, 68-82.

Cassiman, B. and Veugelers, R. (2002), R\&D Cooperation and Spillovers: Some Empirical Evidence from Belgium, American Economic Review 92, 1169-1184.

Ceci, F. and Prencipe, A. (2013), Does Distance hinder Coordination? Identifying and Bridging Boundaries of Offshored Work, Journal of International Management, forthcoming (http://dx.doi.org/10.1016.j.intman.2013.04.001).

Chandler, A.D. (1977), The Visible Hand, Harvard University Press, Cambridge.

Chesbrough, H.W. (2003), Open Innovation - The New Imperative for Creating and Profiting from Technology, Harvard Business School Press, Boston.

Cohen, W.M. and Levinthal, D. (1990), Absorptive Capacity: A new perspective on learning and innovation, Administrative Science Quarterly 35, 128-152.

Contractor, F.J., Kumar, V., Kundu, S.K. and Pedersen, T. (2010), Reconceptualizing the firm in a world of outsourcing and offshoring: the organizational and geographical relocation of high-value company functions, Journal of Management Studies 47(8), 1417-1433.

Cusmano, L., Muncusi, M.L. and Morrison, A. (2009), Innovation and the geographical and organisational dimensions of outsourcing: Evidence from Italian firm-level data, Structural Change and Economic Dynamics 20, 183-195.

D’Agostino, L.M., Laursen, K. and Santangelo, G.D. (2012), The impact of R\&D offshoring on the home knowledge production of OECD investing regions, Journal of Economic Geography, forthcoming (doi: 10.1093/jeg/lbs012).

DeSarbo, W.S., Benedetto, C.A., Song, M. and Sinha, I. (2005), Revisiting the miles and snow strategic framework: uncovering interrelationships between strategic types, capabilities, environmental uncertainty, and firm performance, Strategic Management Journal 26, 47-74.

Di Gregorio, D., Musteen, M. and Thomas, D.E. (2009), Offshore outsourcing as a source of international competitiveness for SMEs, Journal of International Business Studies 40, 969-988.

Dibbern, J., Winkler, J. and Heinzl, A. (2008), Explaining variations in client extra costs between software projects offshored to India, MIS Quarterly 32, 333-366.

Dunning, J.H. and Lundan, S. (1998), The geographical sources of competitiveness of multinational enterprises: an econometric analysis, International Business Review 7, 115-133.

Ebersberger, B. and Herstad, S. (2011), Product innovation and the complementarities of external interfaces, European Management Review 8, 117-135.

Ethiraj, S.K. and Levinthal, D.A. (2004), Modularity and innovation in complex systems, Management Science 50, 159-173.

Fama, E.F. (1980), Agency Problems and the Theory of the Firm, Journal of Political Economy 88, 288-307. 
Fifarek, V., Veloso, F.M. and Davidson, C.I. (2008), Offshoring technology innovation: A case study of rare-earth technology, Journal of Operations Management 26, 222 238.

Frenken, K., Marengo, L. and Valente, M. (1999), Interdependencies, neardecomposability and adaptation, in: Brenner, T. (ed.), Computational Techniques for Modelling Learning in Economics, Kluwer, Boston et al., 145-165.

Gassmann, O. and von Zedtwitz, M. (1999), New concepts and trends in international R\&D organisation, Research Policy 28, 231-250.

Geringer, J.M., Beamish, P.W. and da Costa, R.C. (1989), Diversification strategy and internationalization: Implications for MNE performance, Strategic Management Journal 10, 109-119.

Gianelle, C. and Tattara, G. (2007), Manufacturing abroad while making profits at home: a study on Veneto footwear and clothing global value chains, in: Morroni, M. (ed.), Corporate governance, organisation design and inter-firm relations: theoretical advances and empirical evidence, Edward Elgar, Cheltenham.

Gomes, L. and Ramaswamy, K. (1999), An empirical examination of the form of the relationship between multinationality and performance, Journal of International Business Studies 30, 173-188.

Görzig, B. and Stephan, A. (2002), Outsourcing and firm-level performance, Discussion Papers of DIW Berlin No. 309, German Institute for Economic Research, Berlin.

Granstrand, O., Bohlin, E., Oskarsson, C. and Sjöberg, N. (1992), External Technology Acquisition in Large Multitechnology Corporations, R\&D Management 22, 111-133.

Grote, M. and Täube, F. (2007), When Outsourcing is not an Option: International Relocation of Investment Bank Research, Journal of International Management 13(1), 57-77.

Grant, R.M. (1996), Toward a knowledge-based theory of the firm, Strategic Management Journal 17, 109-122.

Grimpe, C. and Kaiser, U. (2010), Balancing Internal and External Knowledge Acquisition: The Gains and Pains from R\&D Outsourcing, Journal of Management Studies 47, 1483-1509.

Hätönen, J. and Eriksson, T. (2009), 30+ years of research and practice of outsourcing-exploring the past and anticipating the future, Journal of International Management 15(2), 142-155.

Hedlund, G. (1994), A Model of Knowledge Management and the N-form Corporation, Strategic Management Journal 15, 73-90.

Hedlund, G. (1999), The Intensity and Extensity of Knowledge and the Multinational Corporation as a Nearly Recomposable Systems (NRS), Management International Review 39, 5-44.

Helfat, C.E. and Raubitschek, R.S. (2000), Product sequencing: co-evolution of knowledge, capabilities and products, Strategic Management Journal 21, 961-979.

Henderson, R. (1994), The Evolution of Integrative Capability: Innovation in Cardiovascular Drug Discovery, Industrial and Corporate Change 3, 607-630. 
Henley J. (2006), Outsourcing the Provision of Software and IT-Enabled Services to India, International Studies of Management and Organization 36, 111-131.

Herstad, S., Aslesen, H.W. and Ebersberger, B. (2013), On industrial knowledge bases, commercial opportunities and global innovation network linkages, Research Policy, forthcoming (http://dx.doi.org/10.1016/j.respol.2013.08.003).

Hitt, M.A., Hoskisson, R.E. and Ireland, R.D. (1994), A mid-range theory of the interactive effects of international and product diversification on innovation and performance, Journal of Management 20, 297-326.

Hitt, M.A., Hoskisson, R.E. and Kim, H. (1997), International diversification: Effects on innovation and firm performance in product-diversified firms, Academy of Management Journal 40, 767-798.

Hollenstein, H. (2008), Characteristics of Foreign R\&D Strategies of Swiss Firms: Implications for Policy, WIFO Working Papers No. 315, Austrian Institute for Economic Research, Vienna.

Howells, J. (2006), Outsourcing for innovation: systems of innovation and the role of knowledge intermediaries, in: Miozzo, M. and Grimshaw, D. (eds.), Knowledge Intensive Business Services: Organizational Forms and National Institutions, Edward Elgar, Cheltenham, 61-81.

Howells, J., Gagliardi, D. and Malik, K. (2008), The growth and management of R\&D outsourcing: evidence from UK pharmaceuticals, $R \& D$ Management 38, 219.

Ørberg Jensen, P.D. (2009), A Learning Perspective on the Offshoring of Advances Services, Journal of International Management 15, 181-193.

Ørberg Jensen, P.D. and Pedersen, T. (2011), The economic geography of offshoring: the fit between activities and local context, Journal of Management Studies 48(2), 352-372.

Kedia, B.L. and Mukherjee, D. (2009), Understanding offshoring: a research framework based on disintegration, location and externalization advantages, Journal of World Business 44(3), 250-261.

Ketokivi, M. and Ali-Yrkkö, J. (2007), Determinants of Manufacturing-R\&D colocation, Keskusteluaiheita - Discussion papers No. 1082, Research Institute of the Finnish Economy, Helsinki.

Kinkel, S. (2012), Trends in production relocation and backshoring activities: Changing patterns in the course of the global economic crisis, International Journal of Operations \& Production Management 32, 696-720.

Kinkel, S. and Maloca, S. (2009), Drivers and antecedents of manufacturing offshoring and backshoring - A German perspective, Journal of Purchasing and Supply Management 15, 154-165.

Knight, G.A. and Cavusgil, S.T. (1996), The born global firm: A challenge to traditional internationalization theory, in: Cavusgil, S.T. and Madsen, T.K. (eds.), Export internationalizing research: enrichment and challenges, JAI Press, New York, 5-11.

Kogut, B. and Zander, U. (1992), Knowledge of the Firm, Combinative Capabilities, and the Replication of Technology, Organization Science 3, 383-397. 
Kotabe, M., Parente, R. and Murray, J.Y. (2007), Antecedents and Outocmes of Modular Production in the Brazilian Automobile Industry: A grounded Theory Approach, Journal of International Business Studies 38, 84-106.

Kuemmerle, W. (1997), Building effective R\&D capabilities abroad, Harvard Business Review 65, 61-71.

Kuemmerle, W. (1999), The Drivers of Foreign Direct Investment into Research and Development: An Empirical Investigation, Journal of International Business Studies 30, 1-24.

Lacity, M.C. and Willcocks, L.P. (1998), An empirical investigation of information technology sourcing practices: lessons from experience, Management Information Systems Quarterly 22, 363-408.

Lampel, J. and Bhalla, A. (2011), Living with offshoring: the impact of offshoring on the evolution of organizational configurations, Journal of World Business 46(3), 346-358.

Larsen, M.M., Manning, S. and Pedersen, T. (2013), Uncovering the hidden costs of offshoring: The interplay of complexity, organizational design, and experience, Strategic Management Journal 34, 533-552.

Laursen, K., Masciarelli, F. and Prencipe, A. (2012), Regions matter: How localized social capital affects innovation and external knowledge aquisition, Organization Science 23, 177-193.

Levy, D.L. (2005), Offshoring in the New Global Political Economy, Journal of Management Studies 42(3), 685-693.

Lewin, A.Y., Massina, S. and Peeters, C. (2009), Why Are Companies Offshoring Innovation? The Emerging Global Race for Talent, Journal of International Business Studies 40, 901-925.

Liu, R., Feils, D.J. and Scholnick, B. (2011), Why are different services outsourced to different countries? Journal of International Business Studies 42(4), 558-571.

Lundvall, B.-A. (1992), National systems of innovation: towards a theory of innovation and interactive learning, Pinter, London.

Macharzina, K., Oesterle, M.-J. and Brodel, D. (2001), Learning in Multinationals, in: Dierkes, M., Berthoin Antal, A., Child, J. and Nonaka, I. (eds.), Handbook of Organizational Learning \& Knowledge, Oxford University Press, Oxford, 631-656.

Maskell, P., Pedersen, T., Petersen, B. and Dick-Nielsen, J. (2007), Learning Paths to Offshore Outsourcing - From Cost Reduction to Knowledge Seeking, DRUID Working Paper No. 05-17, Copenhagen Business School, Copenhagen.

Medcof, J.W. (2001), Resource-based strategy and managerial power in networks of internationally dispersed technology units, Strategic Management Journal 22(11), 999-1012.

Miles, R.E., Snow, C.C., Meyer, A.D. and Coleman, H.J. (1978), Organizational Strategy, Structure, and Process, Academy of Management Review 3, 546-562.

Mudambi, R. (2008), Location, control and innovation in knowledge-intensive industries, Journal of Economic Geography 8, 699-725. 
Nieto, M.J. and Rodríguez, A. (2011), Offshoring of R\&D: Looking abroad to improve innovation performance, Journal of International Business Studies 42, 345-361.

Nieto, M.J. and Rodríguez, A. (2013), The Challenge of R\&D Offshoring: Implications for Firm Productivity, in: Bals, L., Ørberg Jensen, P.D., Larsen, M. (eds): The Offshoring Challenge, Springer, Heidelberg et al., 175-190.

Nonaka, I. and Toyama, R. (2005), The theory of the knowledge-creating firm: subjectivity, objectivity and synthesis, Industrial and Corporate Change 14, 417436.

Ocasio, W. (1997), Towards an attention-based view of the firm, Strategic Management Journal 18, 187-206.

OECD and Eurostat (2005), The Olso Manual. Recommendations for Collecting and Interpreting Innovation Data. 3rd Edition, Organization for Economic Co-operation and Development, Paris.

OECD (2007), OECD Science, Technology and Industry Scoreboard 2007. Innovation and Performance in the Global Economy, Organization for Economic Co-operation and Development, Paris.

Patel, P. and Vega, M. (1999), Patterns of Internationalisation of Corporate Technology: Location vs. Home Country advantages, Research Policy 28, 145-155.

Peters, B. and Rammer, C. (2013), Innovation Panel Surveys in Germany, in: Gault, F. (ed.), Handbook of Innovation Indicators and Measurement, Edward Elgar, Cheltenham, 135-177.

Prahalad, C.K. and Hamel, G. (1990), The Core Competence of the Corporation, Harvard Business Review 68, 79-91.

Rilla, N. and Squicciarini, M. (2011), R\&D (Re)location and Offshrore Outsourcing: A Management Perspective, International Journal of Management Reviews 13, 393413.

Rivkin, J.W. and Siggelkow, N. (2007), Patterned interactions in complex systems: Implications for exploration, Management Science 53, 1068-1085.

Robson, M.J., Katsikeas, C.S. and Bello, D.C. (2008), Drivers and Performance Outcomes of Trust in International Strategic Alliances: The Role of Organizational Complexity, Organization Science 19, 647-665.

Roza, M., yan den Bosch, F.A.J. and Volberda, H.W. (2011), Offshoring strategy: motives, functions, locations, and governance modes of small, medium-sized and large firms, International Business Review 20(3), 314-323.

Schmeisser, B. (2013), A Systematic Review of Literature on Offshoring of Value Chain Activities, Journal of International Management, forthcoming (http://dx.doi.org/10.1016/j.intman.2013.03.011).

Schmidt, T. (2010), Absorptive Capacity - One size fits all? Managerial and Decision Economics 31, 1-18.

Schmidt, T. and Rammer, C. (2007), Non-technological and Technological Innovation: Strange Bedfellows? ZEW Discussion Paper No. 07-052, Centre for European Economic Research, Mannheim. 
Simon, H.A. (1962), The architecture of complexity: hierarchic systems, Proceedings of the American Philosophical Society 106, 467-482.

Simon, H.A. (1996), The Sciences of the Artificial, MIT Press, Cambridge.

Simon, H.A. (2002), Near decomposability and the speed of evolution, Industrial and Corporate Change 11, 587-599.

Stringfellow, A., Teagarden, M.B. and Nie, W. (2008), Invisible costs in offshoring services work, Journal of Operations Management 26, 164-179.

Sullivan, D. (1994), The "threshold of internationalization": Replication, extension, and reinterpretation, Management International Review 34, 165-186.

Tang, J. and Livramento, H. (2010), Offshoring and Productivity: A Micro-data Analysis, Review of Income and Wealth 56, 111-134.

von Zedtwitz, M. and Gassmann, O. (2002), Market versus Technology Drive in R\&D Internationalization: four Different Patterns of Managing Research and Development, Research Policy 31, 569-588.

Williamson, O.E. (1985), The Economic Institutions of Capitalism: Firms, Markets, Relational Contracting, The Free Press, New York.

Windrum, P., Reinstaller, A. and Bull, C. (2009), The outsourcing productivity paradox: total outsourcing, organisational innovation, and long run productivity growth, Journal of Evolutionary Economics 19, 197-229.

Yayavaram, S. and Ahuja, G. (2008), Decomposability in Knowledge Structures and Its Impact on the Usefulness of Inventions and Knowledge-base Malleability, Administrative Science Quarterly 52, 333-362.

Zhou, Y.M. (2013), Designing for Complexity: Using Divisions and Hierarchy to Manage Complex Tasks, Organization Science, (http://pubsonline.informs.org/doi/ref/ 10.1287/orsc.1120.0744). 
Acknowledgements: We would like to thank two anonymous reviewers, who with their valuable and comments have helped to make the contribution of this paper richer and clearer. We would also like to thank the editor of this journal Professor Michael Kotabe for additional comments and the efficient handling of the review process. Torben Schubert acknowledges financial support from the Swedish Research Council (Linnaeus Grant No. 349200680) and the Swedish Governmental Agency for Innovation Systems (Grant agreement 2010-07370). 